\title{
Determinants of Participation of Farmers in the E-wallet Agricultural Input Delivery System in Abia State Nigeria
}

https://dx.doi.org/10.4314/jae.v22i3.11

\section{Agbarevo, Machiadikwe N.}

Department of Agricultural Extension and Rural Development

Michael Okpara University of Agriculture, Umudike, Abia State, Nigeria

E-mail: machibenevo@gmail.com. Phone: 07035787023

\section{Ukagha, Onyinyechi}

Department of Agricultural Extension and Rural Development

Michael Okpara University of Agriculture, Umudike, Abia State, Nigeria

E-mail: onyipresh1@gmail.com. Phone: 08095491632

\section{Abstract}

The study determined the factors influencing farmers' participation in the Scheme in Abia State, Nigeria. A multi-stage sampling technique was used to select a sample of 162 farmers, who are participating in the E-wallet scheme. In the first stage, the State was divided into the three Extension Zones of the State ADP. In the second stage, 2 blocks were selected from each of the three Zones, giving a total of 6 blocks out of 54 blocks. In the third stage, 3 sub-circles were selected from each block, giving a total of 18 sub-circles. In the fourth stage, 9 farmers were selected from each sub-circle, giving a total of 162 farmers as the sample size. Data for the study were collected through the use of a structured questionnaire. The null hypothesis was tested using inferential statistics (Ordinary Least of Squares model of regression analysis). The study found a significant influence of the selected socioeconomic factors on farmers' participation in the E-wallet Scheme as seven out of the eleven factors were significant at $1 \& 5 \%$ level. The factors included: sex, marital status, E-wallet experience, farm size, farming as main occupation, yield, and co-operative membership; while age, income, education and farming experience were not significant. The study concluded that the Scheme was achieving its goal of improving farmers' yield since the influence of yield and previous participation in the Scheme were very significant at $1 \%$. The study recommended among others, more publicity of the Scheme and registration of more farmers into the scheme because it is leading to increase in farmers' yield, which in turn would help in achieving food security.

key words: Determinants, farmers, participation, e-wallet, input, delivery

\section{Introduction}

Farmers in rural areas often find it difficult to access farm inputs, which apparently leads to low productivity, increased poverty, unemployment and lack of interest in farming. Hence, there is need to ensure that farmers have easy access to farm inputs, such as fertilizer, seeds; agro-chemicals, etc., and necessary information to improve their production and productivity. 
Creative commons User License: CC BY-NC-ND

Abstracted by: EBSCOhost, Electronic Journals Service (EJS), Google Scholar, Journal Seek, Scientific Commons,

Food and Agricultural Organization (FAO), CABI and Scopus
Journal of Agricultural Extension

Vol. 22 (3) October, 2018

ISSN(e): 24086851; ISSN(Print); 1119944X

http://journal.aesonnigeria.org

http://www.aiol.info/index.phpliae

Email: editorinchief@aesonnigeria.org

E-wallet has been defined as an efficient and transparent electronic device or system that makes use of vouchers for the purchase and distribution of agricultural inputs (Ezeh 2013, Adesina 2013). It is also an online prepaid account used to store money and transact online and offline through a computer or smart phone whenever required. It is a pre-equipped electronic wallet, which just like a real wallet, is used by the customer to transact immediately securely.

According to Adesina (2013), E-wallet approach is designed mostly for small holder farmers who are having low fertilizer and other inputs for production. It is being supported by the Growth Enhancement Support Scheme (GESS),which was established and implemented from October 2011, with the hope that the needs of farmers particularly in areas of innovations, input supply, seedlings and fertilizer distribution can be met through the utilization of e-wallet (a mobile phone platform where registered farmers can be reached by agricultural development agencies) in order to create direct access thereby cutting off middlemen and reducing the cost of fertilizer and non-availability of unprocessed and unadulterated input in the market (Score Card, 2013). The goal of this scheme is to provide subsidized agricultural inputs, such as fertilizers, hybrid seeds and agro-chemicals to farmers, to remove the usual complexities associated with input distribution in order to increase farmers' productivity, income and promote food security.

In view of this, in July 2012, the Federal Government of Nigeria introduced the Growth Enhancement Support Scheme (GESS), which is designed to deliver government subsidized farm inputs directly to farmers by informing them via GSM phones. The GESS is powered by E-wallet, which provides an efficient and transparent system for the distribution and purchase of agricultural inputs based on a voucher system. The scheme guarantees registered farmers of E-wallet access to fertilizer, seeds and other agricultural inputs from agro dealers at half the cost. The Federal and State Governments take care of the other half. (Ezeh, 2013). With worldwide access, e-wallets are an excellent tool to facilitate online payments.

The E-wallet system was introduced in Nigeria in 2012 by the then Minister of Agriculture Dr. Akinwumi Adesina, and was launched in Abia State in the same year. In 120 days, over 1.2 million farmers bought their subsidized fertilizers using the ewillet system. A total of $138,802.7$ metric tons of fertilizer and 10,974.78 metric tons of seeds were distributed in 517 active redemption centres out of all the 804 centres spread across the Federation (Adesina, 2013).

Nigeria's aggregate agricultural output remains extremely low relative to other developing countries. This is because farmers have been finding it difficult to purchase farm inputs and obtain required quantity at the right time. Also, the procurement and distribution of fertilizer and seeds have been faced with fraudulent practices. Federal and state governments had hitherto been spending a lot of money on farm inputs, which were not reaching the intended beneficiaries, mostly small holder farmers. The poor distribution as well as procurement of fertilizer, grossly affected farmers' productivity and income. This made the Federal Government of Nigeria to opt out of direct procurement and distribution of agricultural inputs to farmers but instead, instituted the Growth Enhancement Support Scheme (GESS), 
Creative commons User License: CC BY-NC-ND

Abstracted by: EBSCOhost, Electronic Journals Service (EJS), Google Scholar, Journal Seek, Scientific Commons,

Food and Agricultural Organization (FAO), CABI and Scopus
Journal of Agricultural Extension

Vol. 22 (3) October, 2018

ISSN(e): 24086851; ISSN(Print); 1119944X

http://journal.aesonnigeria.org

http://www.aiol.info/index.phpliae

Email: editorinchief@aesonnigeria.org

which is aimed at delivering subsidized farm inputs to farmers through an electronic wallet (Etuh, 2012).

However, with the introduction of the E-wallet system, it is expected that the farmers would be able to access farm inputs easily and at cheap cost. But whether this expectation has been met in Abia State is apparently unknown, and needs to be investigated. This would help in finding out whether the E-wallet has been effective in input delivery, or not.

Growth Enhancement Support Scheme (GESS) is an indispensable platform for agro input delivery to farmers, and was adopted for farmers to connect with government to receive relevant information particularly in areas of agricultural innovations, technology and input supply and distribution through utilization of electronic wallet (Ewallet) to create access to farmers (Adesina, 2012). This innovative scheme seeks to remove the difficulties confronting the agricultural sector in Nigeria and ensuring availability of fertilizer, seeds and other inputs to farmers as timely as possible. This is with the understanding that the corruption which has been the bane of agricultural development in Nigeria would be better tackled if and when farmers can directly access government appointed distributors of agro inputs through their mobile phones (Ezeh, 2013). The scheme is said to have effectively gotten the Government out of direct procurement and distribution of farm inputs and simultaneously bringing the private sector such as financial institutions, agro-dealers, suppliers, marketers, etc., into the value chain for agricultural inputs supply and distribution (NAN, 2012). Through the e-wallet farmer receive and pay for GESS from both the Federal and State Governments and are linked to agro-dealers, suppliers, extension services, financial institutions, etc. According to Kamani and Kathiriya (2014), more and more farmers are becoming technology savvy and getting involved with the new media to connect with other stakeholders at personal level.

For a farmer to participate, he or she must be above 18 years old, must have participated in a survey authorized by government to capture farmers' personal detailed information, he must own a cell phone with registered SIM card and have at least sixty-Naira credit in the cell phone. The fulfilment of these conditions guarantees the insurance of an e-wallet vouchers to the farmer. The voucher is used to redeem fertilizers, seeds and other agricultural inputs from agro-dealers at half the cost (Signal, 2014).

Some of the challenges of farmers in implementing the e-wallet approach include insufficient fertilizer and late arrival of inputs. These constraints occur due to delay on the part of agro dealers and the manufacturing companies. Furthermore, inadequate quantity of fertilizer subsidy is among the constraints to effective distribution in Nigeria (IFPRI, 2010). Low literacy rate among the farmers is another factor that makes it impossible for the farmers to access the inputs through the use of phone. Poor network many at times make it difficult to receive text messages with E-wallet system. The coverage of some of the network providers is restricted to particular areas hence, most farmers may have limited network coverage, thereby posing challenges to farmers in getting their packages.

The Point of Sales (POS) is a device that records electronic transactions both offline and online. It will be used by agro-dealers to make electronic transactions during the 
redemption process, with the NUMC card that farmers will present for unique identification. They both aim to provide agro-dealers with an electronic device that has the capacity to work in offline and online modes. This means that no redemption can be made without GES card and that all sales will be recorded electronically, removing some of the key opportunities for fraud. All records there would be transmitted electronically when the devices are brought into network coverage, which should reduce the reconciliation time dramatically and improve agro-dealer liquidity. The electronic system also improved access to accurate data in a transparent, efficient and timely manner.

The GESS is an innovative scheme, which seeks to remove the difficulties usually associated with the distribution of fertilizers and hybrid seeds to farmers. In the past there were complaints of diversion, exorbitant cost and adulteration of various inputs to farmers, which ultimately led to low productivity, increased poverty, unemployment and lack of interest in farming. Thus, the objectives of the GESS are to:

i. provide subsidized agricultural inputs and services and agro-chemicals to farmers;

ii. remove the usual complexities associated with fertilizer distribution;

iii encourage critical actors in the fertilizer value chain to work together to improve productivity;

iv. enhance farmers income and promote food security, creating of wealth, creating of jobs for women and youths making Nigeria a major player in the global market; and

v. shift provision of subsidized agro-inputs and services away from a general subsidy to genuine small holder farmers (Adesina, 2013). It is the objective of this paper to determine the extent of influence of the various factors influencing farmers' participation in the E-wallet system of agricultural input delivery.

\section{Methodology}

In conducting the study, a multi-stage sampling technique was used to select a sample of 162 farmers, who are participating in the E-wallet scheme. In the first stage, the State was divided into the three Extension Zones of the State. In the second stage, 2 blocks were selected from each of the three Zones, giving a total of 6 blocks out of 54 blocks. In the third stage, 3 sub-circles were selected from each block, giving a total of 18 sub-circles. In the fourth stage, 9 farmers were selected from each sub-circle, giving a total of 162 farmers as the sample size. Data for the study were collected through the use of a structured questionnaire. The null hypothesis was tested using inferential statistic (Ordinary Least of Squares model of regression analysis, implicitly expressed as:

$$
\begin{aligned}
& Y=F\left(X_{1}, X_{2}, X_{3}, X_{4}, X_{5} \ldots \ldots \ldots . . . X_{n}, \text { ei }\right) \\
& Y=\text { Participation in E-wallet (participate }=1, \text { otherwise }=0) \\
& X_{1}=\operatorname{Sex}(\text { male }=1, \text { female }=0)
\end{aligned}
$$




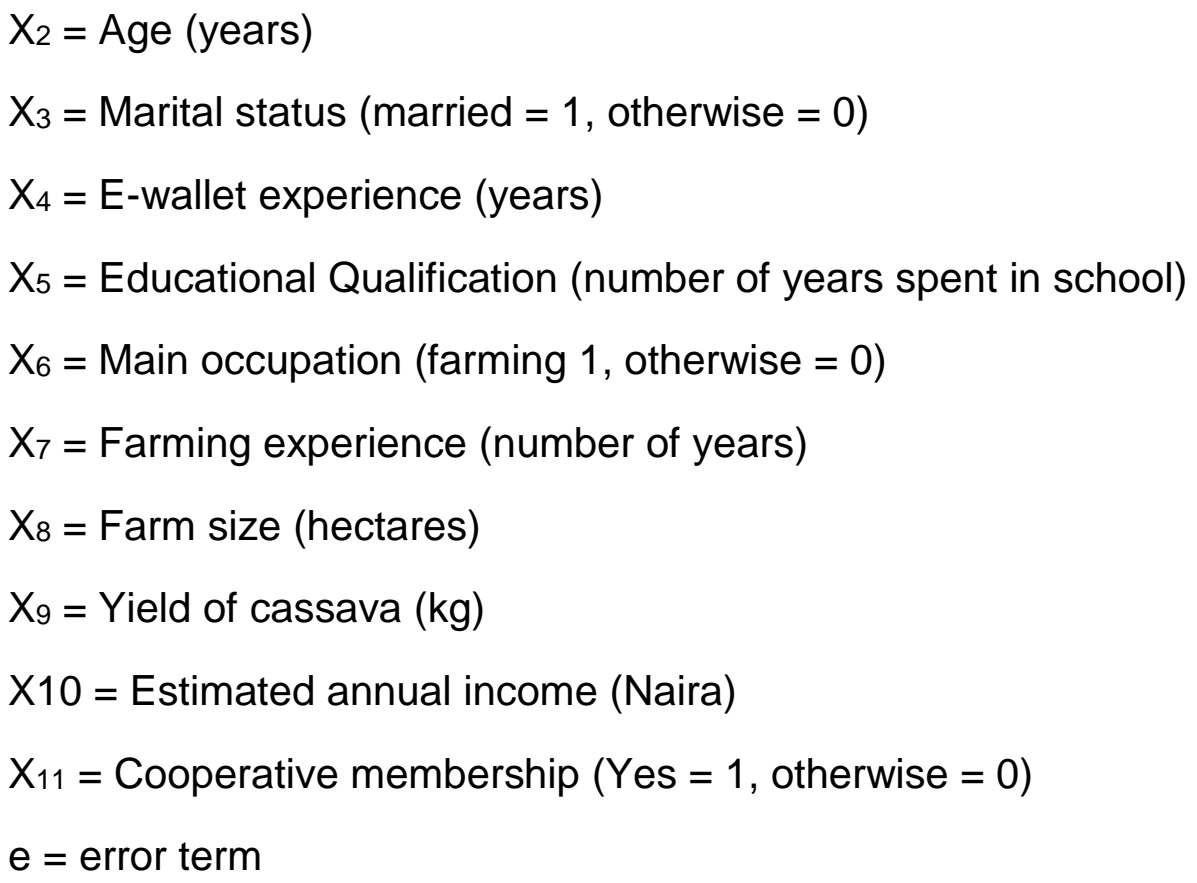

\section{Results and Discussion}

\section{Effect of Farmers' Socio-Economic Characteristics on participation}

Table 1 reveals the regression estimate of the effect of selected socio-economic characteristics of farmers on participation in the E-wallet scheme. The Table shows that marital status has the greatest influence on participation with a t-value of 19.197 which is significant at $1 \%$. This shows that married people with families to take care of, participated more actively in the E-wallet scheme than unmarried people because of need for greater profit to feed their families. In this regard, Omoare et al. (2014) opined that large household size would require more funds or income to meet family needs, married people engage in activities that can help them raise money to take care of their families. Another factor that significantly influenced participation of the farmers in E-wallet was sex with a t-value of 17.267 which was significant at $1 \%$. According to Ogbonna and Nwaobiala (2014), sex influences many human activities, which supports the finding of the study. The result also shows that E-wallet experience influences the participation of farmers in the scheme with a t-value of 9.191 which was significant at $1 \%$. Nwaobiala (2014), noted that number of years of participation in E-wallet scheme has shown to encourage farmers to make decisions on sourcing of farm inputs and appropriate technologies to employ on their farms.

Another factor that significantly influenced participation of the farmers in e-wallet was farm size, with a t-value of 6.231 , which was significant at $1 \%$ level of probability. This implies that the larger the farm size, the more the farmer participated in the E-wallet input delivery system. This is because the bigger the farm size, the greater the farm inputs needed This is in line with Jayne et al. (2005) and Delninger (2003) as they 
Creative commons User License: CC BY-NC-ND

Abstracted by: EBSCOhost, Electronic Journals Service (EJS),

Google Scholar, Journal Seek, Scientific Commons,

Food and Agricultural Organization (FAO), CABI and Scopus
Journal of Agricultural Extension

Vol. 22 (3) October, 2018

ISSN(e): 24086851; ISSN(Print); 1119944X

http://journal.aesonnigeria.org

http://www.ajol.info/index.php/iae

Email: editorinchief@aesonnigeria.org

opined that the larger the farm size of the household, the inputs required, and the higher the expected level of food production.

Yield of cassava also influenced the participation of farmers on e-wallet with a t-value of 6.020 , which was significant at $1 \%$. This shows that e-wallet has been very helpful in increasing the yield of farmers arising from inputs purchased, which increased willingness to participate more in the scheme. This finding is supported by Ezeh (2013) who noted that e-wallet benefits farmers and increases their productivity. Other factors included co-operative membership, with a t-value of 2.076, which was significant at $5 \%$. This indicates that cooperative membership increases use of $e$ wallet, which in turn leads to easy access to inputs, with positive effect on farmers' productivity. This implies that e-wallet system encourages and facilitates farmers to form groups and engage in training activities of the scheme. This result is in consonance with findings of Ibitoye (2012) and Umeokeke et al.(2017), who reported that E-wallet system impacted positively on farmers' welfare as well as enhanced household chances of improved living.

Table 1: Regression estimate of the effect of selected socio-economic characteristics on participation in E-wallet

\begin{tabular}{llll} 
Parameters & Estimate & Standard error & T-Value \\
\hline Sex & 2.227 & 0.536 & $17.267^{* \star *}$ \\
Age & -0.034 & 0.041 & 0.687 \\
Marital Status & 3.568 & 0.814 & $19.197^{* \star *}$ \\
E-wallet experience & -0.902 & 0.297 & $9.191^{* * *}$ \\
Education & 0.185 & 0.359 & 0.267 \\
Occupation & -0.303 & 0.211 & $2.051^{* *}$ \\
Farming experience & -0.032 & 0.043 & 0.571 \\
Farm size & 0.895 & 0.359 & $6.231^{* * *}$ \\
Yield of cassava & -5.630 & 0.000 & $6.020^{* * *}$ \\
Income & 2.2330 & 0.000 & 0.080 \\
Co-operative & 0.680 & 0.472 & $2.076^{* *}$ \\
membership & & & \\
Psuedo - R ${ }^{2} 0.504$ & & & \\
Log-likelihood 466.729 & & \\
Chi-square 1781.153 & & & \\
\hline
\end{tabular}

*** $\mathrm{P} \leq 0.01{ }^{* *} \mathrm{P} \leq 0.05$; Source: Field survey, 2017 


\section{Conclusion and Recommendations}

The result of this study has shown that the respondents perceived the E-wallet as helpful in input delivery. This implies that, Growth Enhancement Support Scheme through e-wallet is succeeding in eliminating the obstacles that limit farmers' access to agricultural inputs. Extension agents should be involved in the scheme to help disseminate information since network problems hinder communication under the scheme. Registration into the scheme should be less cumbersome to encourage greater participation of farmer. There should be cooperative formation among farmers to enhance access to farm inputs.

\section{References}

Adesina, A. (2012). Growth enhancement support scheme. Save Agricultural Sector. Punch Newspaper. Retrieved from http://www.punch.ng.com/business/industryGESS.

Adesina B. (2013). A speech by the Honourable Minister of Agriculture and Rural Development, Federal Republic of Nigeria at the $36^{\text {th }}$ Session of the IFAD Governing Council in Rome.

Agricultural Analysis; Innovative solution (2013). Agriculture in Nigeria 2013 Oxfam, Nigeria Abuja, FMARD, Abuja Author.

Etuh, T. (2012). "The Growth Enhancement Support Scheme (GESS)" monitoring report: submitted to the Honourable Minister of Agriculture and Rural Development. By the fertilizer suppliers Association of Nigeria.

Eze, A. N. (2013). Access and Application of Information and Communication Technology (ICT) Among Farming Household of East Nigeria. Agriculture and Biology Journal of North America. Doi: 10.5251/abjna.2013.4.6.605.616.

Federal Ministry of Agriculture and Rural development (FMARD), Nigeria (2013). GES live data dashboard. retrieved on 02/12/2014 from http://www.fmard.gov.ng/geslive.data.dashboard.

Federal Ministry of Agriculture and Rural Development, Abuja, Nigeria (2011). Agricultural Transformation Agenda; We will grow Nigeria's Agricultural sector, Retrieved from: http/www.unaab.edu.ng/attachments/Agricultrual\%20blue\%20printpdf accessed on March 25, 2014.

Federal Republic of Nigeria (FRN) (2013). Federal Government Intensifies efforts at Guaranteeing Farmers Access to Inputs, Flags- off $2^{\text {nd }}$ Phase of GES in Southwest.

Ibitoye, S.J. ( 2012). Survey of performance of agricultural cooperative societies in Kogi State, Nigeria. Available at www.emeraldinsight.com.accessed on 03/10/2018.

International Food Policy Research Institute (IFPRI) (2010). A Review of Fertilizers Policy Issues in Nigeria. Nigeria Strategy Support Program (NSSP) NSSP working Paper No. 0019. Available on http://www.ifpri.org/sites/default/files/publications/nsswp191.pdf access 
Creative commons User License: CC BY-NC-ND

Abstracted by: EBSCOhost, Electronic Journals Service (EJS),

Google Scholar, Journal Seek, Scientific Commons,

Food and Agricultural Organization (FAO), CABI and Scopus
Journal of Agricultural Extension

Vol. 22 (3) October, 2018

ISSN(e): 24086851; ISSN(Print); 1119944X

http://journal.aesonnigeria.org

http://www.ajol.info/index.php/jae

Email: editorinchief@aesonnigeria.org

on March 25, 2014.

Omoare, A.M., Fakoya, E.O., Fapojuwo, E.O., and Oyediran, W.O. (2014). Assessment of value Addition in value chain of sweet potato (Ipomoea batatas (L) Lamjin Osun State, Nigeria. World Academy of Science, Engineering and Technology (WASET) 85, 2014, 537-540. http://waset.org/publications? $p=85$.

Score card (2013). Agricultural Transformation Agenda. Mid Term Report. Abuja: FMARD.

Signal Alliance (2014). ERP for the Agriculture Sector in Nigeria.

Transforming Big Data into Big value in Agriculture Industry. Retrieved from http://www.slideshare.net//signalaviance/erp.for the agriculture-in-Nigeria accessed on April 23, 2014.

Umeokeke et al.(2017). Impact of E-wallet system on farmers' welfare in Oyo State, Nigeria. Available at www.emeraldinsight.com. accessed on 03/10/2018. 